\title{
MAGNETICALLY STIMULATED CHANGES IN THE ELECTROPHYSICAL PROPERTIES OF THE NEAR-SURFACE SILICON LAYER
}

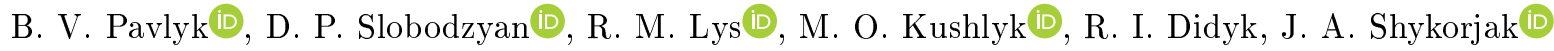 \\ Ivan Franko National University of Lviv, \\ Department for Sensor and Semiconductor Electronics, \\ 107, General Tarnavsky St., Lviv, UA-79017, Ukraine, \\ e-mail: bohdan.pavlyk@lnu.edu.ua
}

(Received 04 May 2020; in final form 21 June 2020; accepted 23 June 2020; published online 15 October 2020)

\begin{abstract}
This papers presents the results of the influence of a weak magnetic field (MF) $(0.354 \mathrm{~T})$ on the electrophysical properties of surface structures based on p-Si. A 300-hours exposure of singlecrystal silicon samples in a magnetic field stimulates the decay of hydrogen-containing and oxygencontaining surface complexes $\left(\mathrm{C}-\mathrm{H}_{X}, \mathrm{Si}-\mathrm{O}-\mathrm{H}, \mathrm{O}-\mathrm{H}\right)$ and the formation of $\mathrm{Si}-\mathrm{H}_{3}$ centers. As a result, the surface resistance increases and the barrier properties of the $\mathrm{Bi}-\mathrm{Si}(\mathrm{p})$ contact deteriorate

Key words: silicon, magnetic field, elastic mechanical deformation, current-voltage characteristic, capacitance-voltage characteristic, IR absorption spectra.
\end{abstract}

DOI: https://doi.org/10.30970/jps.24.3702

\section{INTRODUCTION}

Modern semiconductor electronics requires a search for new materials or modification of existing ones to register small fluctuations of weak electromagnetic fields. By using a magnetic resonance analysis for semiconductor and dielectric structures, a method to the verify data collected is required to ensure the absence of a probing field influence on processes in the analysed samples.

As shown in $[1,2]$, the main cause of diamagnetic materials' sensitivity to weak magnetic fields is spindependent processes in imperfect crystals related to the removal of the spin-forbidden principle in defect complexes and their further disintegration. However, they cannot be implemented in a thermodynamicallyequilibrium system working only when there's a thermodynamic ambiguity between the initial and the final states of the system. Furthermore the conditions in which a weak MF (magnetic field) could maintain great polarization of the spin system need to be created, without which it is impossible to achieve significant macroscopic effects.

However, magnetically stimulated processes are more efficient in the presence of the considerable amount of structural (linear in particular) defects in subsurface layers of semiconductors [3-6]. In addition, the efficiency of such processes is affected by the magnetic field exposure time $[7,8]$ as well as by the precence of absorbed atoms or molecules that cause changes of the impurity composition of subsurface layers and the charge state of the surface $[9,10]$.

Treatment with weak magnetic fields can deliberately change the properties of semiconductors and semiconductor-based structures [11-15].

The aim of the work was to establish the origin of the silicon structures' sensitivity to a weak magnetostatic field and to investigate the degradation of the electrophysical and electromechanical characteristics of those structures after 300 hours of the magnetic field exposure.

\section{METHODOLOGY}

In this research, single-crystalline silicon samples of a $p$-type conductivity doped with boron and $10 \mathrm{Ohm} / \mathrm{cm}$ of resistivity were used. The dimensions of the experimental samples were $3 \times 3 \times 8 \mathrm{~mm}^{3}$.

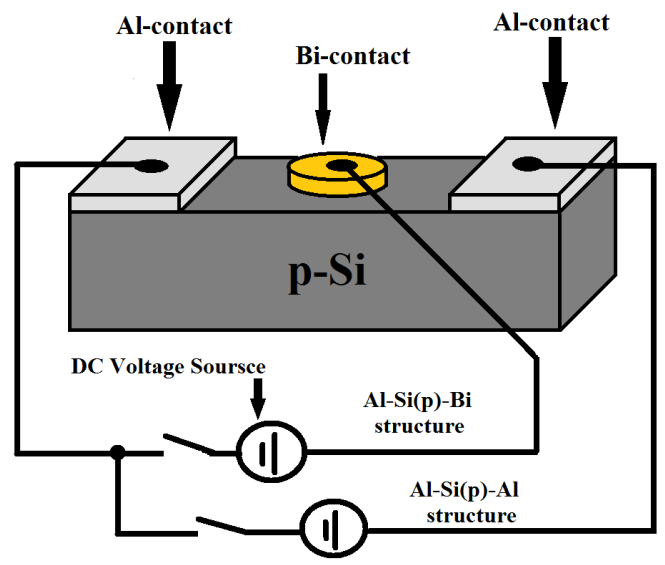

Fig. 1. Silicon sample with metal contacts

On the surface (111) of the sample, silicon structures were formed by using a method of thermal vacuum evaporation of aluminium (ohmic contact) and bismuth (barrier contact) [10]. It allowed us to prepare two different metals on one surface by one vacuuming cycle. $\mathrm{As}$ a result, structures $\mathrm{Al}-\mathrm{Si}-\mathrm{Al}$ and $\mathrm{Bi}-\mathrm{Si}-\mathrm{Al}$ (Fig. 1 ) were formed for further research into their surface and volume electroconductivity and rectifying properties of the Schottky barrier.

Defect formation processes on the surface and subsurface layers of silicon crystals were analysed by IR spectroscopy [16].

Using this method, the composition of adsorbed complexes was determined as well as their role in the defect formation and in changing the crystal conductivity. IR spectra of the experimental samples were measured in the absorption mode the in $500-4000 \mathrm{~cm}^{-1}$ range on 
the IR spectrometer Specord 75 IR.

Electrophysical properties of the $\mathrm{Bi}-\mathrm{Si}-\mathrm{Al}$ structure were studied by measuring and analysing the currentvoltage characteristic (IVC) and the high-frequency capacitance-voltage characteristic (CVC) curves. From the experimental $\mathrm{C}-\mathrm{V}$ characteristics, the distribution of surface-state density in silicon's bandgap on the boundary of $\mathrm{Si}-\mathrm{SiO}_{2}$ was calculated [16].

Measurements of the electrical resistance of $p$-Si single crystals as a function of the elastic mechanical stress ( $R=f(\sigma)$ ) were carried out on a self-made research complex, which included the dynamometer XK3118T1 and the millivoltmeter $\mathrm{B} 7-34 \mathrm{~A}$, with results being recorded every second to a computer. The compression velocity was $8 \mu \mathrm{m} / \mathrm{min}$.

Magnetic processing of the samples was carried out by exposing them for 300 hours to a magnetostatic field $(B=0.354 \mathrm{~T})$ in the ambient atmosphere and in a darkened working chamber at room temperature.

\section{RESULTS}

Figure 2 shows the characteristic curve of the resistance changes over the exposure time in the magnetostatic field in $\mathrm{Al}-\mathrm{Si}-\mathrm{Al}[18]$. It can be seen that the magnitude of the surface resistance increased by $5.5 \%$ over 1200 hours of the samples' exposure to the MF. However, further exposure leads to a drop in resistance. Moreover, such cycle of $R=f(t)$ tends to recur, but with a different exposure time. It should be noted that when exposing the samples to the MF for up to 5000 hours, the magnitude of the surface electrical resistance only changes by up to $6.3 \%$ from an initial value.

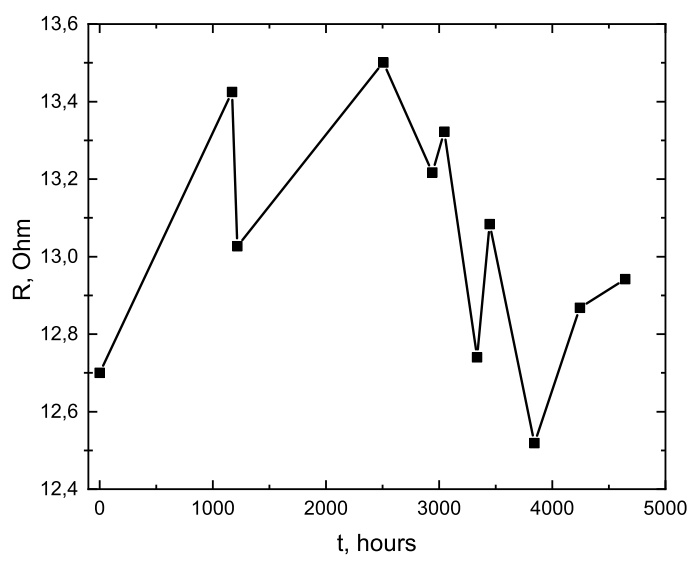

Fig. 2. Dependence of the resistance of a single $p$-Si crystal on the time spent in a magnetic field

The increase in resistance at the initial stage of the exposure of the $\mathrm{Al}-\mathrm{Si}-\mathrm{Al}$ structure to the MF (up to 1200 hours) can be associated with spin-related processes of the decomposition of absorbed hydrogen-containing impurities [10].

In Fig. 3 the IR absorption spectrum of single crystalline silicon samples is shown before and after 300 hours of the exposure to the MF.

For the as-grown sample there are several groups of peaks in three areas [19]:

$\mathrm{I}-4000-2500 \mathrm{~cm}^{-1}$ is the area of valence vibrations of single bonds $(X-\mathrm{H}, \mathrm{O}-\mathrm{H}, \mathrm{N}-\mathrm{H}, \mathrm{C}-\mathrm{H}, \mathrm{S}-\mathrm{H})$,

II $-2500-1500 \mathrm{~cm}^{-1}$ is the area of valence vibrations of multiple bonds $(X=Y, X \equiv Y, \mathrm{C}=\mathrm{C}, \mathrm{C}=\mathrm{O}$, $\mathrm{C}=\mathrm{N}, \mathrm{C} \equiv \mathrm{C}, \mathrm{C} \equiv \mathrm{N})$,

III $-1500-500 \mathrm{~cm}^{-1}$ is the area of valence vibrations $(X-Y, \mathrm{C}-\mathrm{C}, \mathrm{C}-\mathrm{N}, \mathrm{C}-\mathrm{O})$ and deformation fluctuations of single bonds $(X-\mathrm{H}, \mathrm{C}-\mathrm{H}, \mathrm{O}-\mathrm{H}, \mathrm{N}-\mathrm{H})$.

By comparing the results with the literature data $[16,20,21]$, it was established that these peaks correspond to hydrogen-, oxygen- and carbon-containing complexes and their connections with silicon atoms (see Table 1).

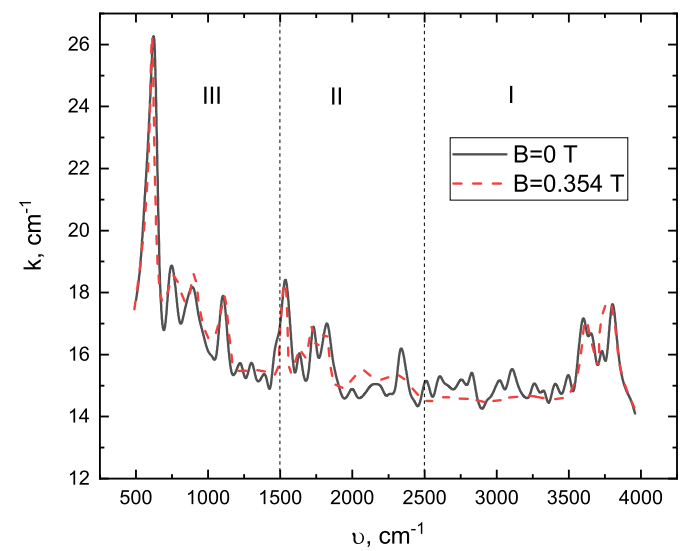

Fig. 3. Infrared absorption spectra of the p-Si sample before and after 300 hours of exposure to the MF

Peaks of IR spectra in the range from $3000 \mathrm{~cm}^{-1}$ to $3800 \mathrm{~cm}^{-1}$ correspond to the absorption of $\mathrm{O}-\mathrm{H}$ bonds vibrations, particularly in water molecules $\left(3619 \mathrm{~cm}^{-1}\right)$, which adsorbed on the surface and in $\mathrm{Si}-\mathrm{O}-\mathrm{H}$ bonds $\left(3401 \mathrm{~cm}^{-1}\right)$. There are many low-intensity bands in the range $2500-2840 \mathrm{~cm}^{-1}$, which can be identified as absorption due to the $\mathrm{C}-\mathrm{H}_{X}$ bonds.

\begin{tabular}{|c|c|c|c|}
\hline$\lambda(\max ), \mathrm{cm}^{-1}$ & Complex & $\lambda(\max ), \mathrm{cm}^{-1}$ & Complex \\
\hline 612,900 & $\mathrm{Si}-\mathrm{H}_{2}$ & $1720-1820$ & $\mathrm{C}=\mathrm{O}$ \\
\hline 750 & $\mathrm{Si}-\mathrm{C}$ & $1990-2200$ & $\mathrm{Si}-\mathrm{H}_{3}$ \\
\hline 1100 & $\mathrm{O}-\mathrm{Si}-\mathrm{O}$ & 2340 & $\mathrm{O}_{3}-\mathrm{Si}-\mathrm{H}$ \\
\hline 1220 & $\mathrm{Si}-\mathrm{O}-\mathrm{C}$ & $2500-2840$ & $\mathrm{C}-\mathrm{H}_{X}$ \\
\hline $1310-1530$ & $\mathrm{C}-\mathrm{CH}_{3}$ & $3000-3500$ & $\mathrm{Si}-\mathrm{O}-\mathrm{H}$ \\
\hline 1620 & $\mathrm{C} \equiv \mathrm{C}$ & $3590-3800$ & $\mathrm{O}-\mathrm{H}$ \\
\hline
\end{tabular}

Table 1. Absorption maximums and corresponding defect structures of the $p$-Si sample

Absorption in the ranges of 1990-2200 cm-1 and 2340 $\mathrm{cm}^{-1}$ is related to fluctuations of silicon complexes $\mathrm{Si}-\mathrm{H}_{3}$ 
and $\mathrm{O}_{3}-\mathrm{Si}-\mathrm{H}$ respectively. Absorption bands on 1620 $1820 \mathrm{~cm}^{-1}$ are identified as valence fluctuations of multiple bonds $\mathrm{C}=\mathrm{O}$ and $\mathrm{C} \equiv \mathrm{C}$.

Band peaks between $1310-1530 \mathrm{~cm}^{-1}$ correspond to the deformation mode $\mathrm{C}-\mathrm{CH}_{3}$, and the range $612-$ $1220 \mathrm{~cm}^{-1}$ is related to adsorption processes of carbon and water on the silicon surface, as well as the silicon oxidation process $\left(1100 \mathrm{~cm}^{-1}\right)$ [19].

After the magnetic treatment, a decrease in the amplitude of the absorption coefficient in the range of the wave vector from 2500 up to $3800 \mathrm{~cm}^{-1}$ can be observed on the IR spectrum (Fig. 3). In particular, the concentration of absorption centres, which correspond to valence fluctuations of single bonds with hydrogen $\left(\mathrm{C}-\mathrm{H}_{X}, \mathrm{Si}-\mathrm{O}-\right.$ $\mathrm{H}, \mathrm{O}-\mathrm{H})$, is decreasing. As a result, the released hydrogen can migrate on the surface and passivate acceptors [22]. This is confirmed by an increase in peaks amplitude, which corresponds to $\mathrm{Si}-\mathrm{H}_{3}$ complexes.

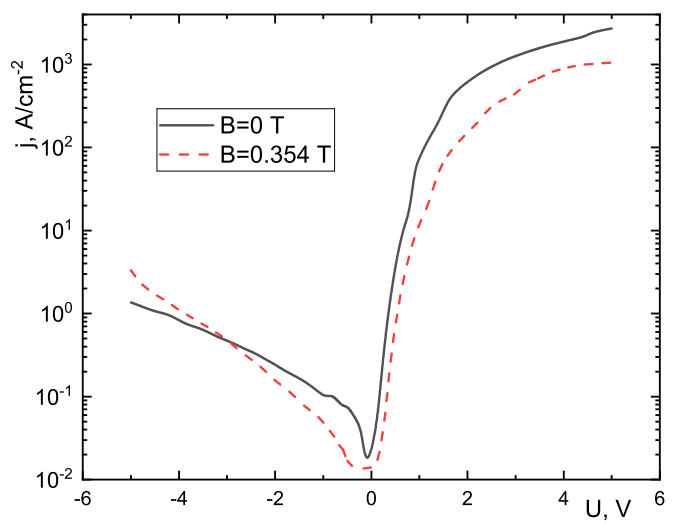

Fig. 4. The current-voltage characteristic of the barrier structure $\mathrm{Bi}-\mathrm{Si}-\mathrm{Al}$ before and after 300 hours of exposure to the MF

In Fig. 4, the current-voltage curve of $\mathrm{Bi}-\mathrm{Si}-\mathrm{Al}$ is shown before and after processing in the MF. 300 hours of such exposure causes a decrease in the current density through $\mathrm{Bi}-\mathrm{Si}(\mathrm{p})$ contact in the voltage range from -3 to $+5 \mathrm{~V}$.

As shown earlier, the magnetic treatment causes the reconstruction of hydrogen-containing surface complexes in silicon subsurface layers. As a result, the charge state of electrically active centres changes and their neutralization occurs. Consequently, a decrease in conductivity may happen [23].

Along with this, in theoretical models of barrier structures, it is considered that the major influence on IVC is caused by surface states (SS), which exist on the boundary. It is known [10] that magnetic field exposure leads to an increase in surface states density on $\mathrm{Si}-\mathrm{SiO}_{2}$ interphase boundary and to a change in the charge state of the oxide.

In Fig. 5, the capacitance-voltage characteristic of the barrier structure and the density distribution of quick surface states in the silicon bandgap on the $\mathrm{Si}-\mathrm{SiO}_{2}$ border in samples after 300 hours of the magnetic fi- eld exposure are shown. After analyzing these graphical results, we can identify the presence of the following two processes.

First: the reduced density of states near the valence band and near the midgap of silicon. It is related to the passivation of acceptor bonds with hydrogen and the corresponding restructuring of the defect structure in the silicon subsurface layer.

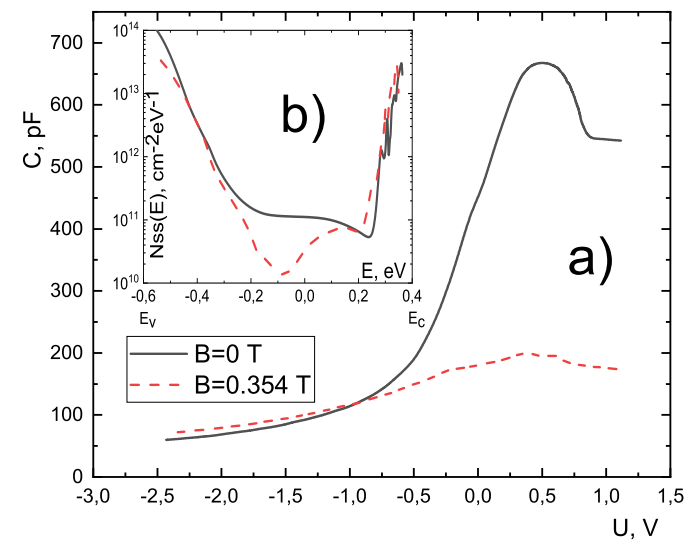

Fig. 5. Magnetically stimulated changes of the capacitancevoltage characteristic of barrier structure (a) and density distribution of quick surface states in silicon bandgap on the $\mathrm{Si}-\mathrm{SiO}_{2}$ border (b)

Second: a decrease in the capacity value on CVC peak in the positive voltage area and on insignificant increase in the states density near the conductivity band (0.2-0.4 $\mathrm{eV})$. The reason is the negative charge accumulation on the silicon oxide boundary.

The effect of the MF can lead to a dynamic polarization of the atomic nucleus in silicon isotope $\mathrm{Si}^{29}$ and the electron spins polarization of silicon's and impurity's (oxygen's) atoms caused by superfine coupling with the polarized nucleus $[24,25]$. As a result, on boundary $\mathrm{P}_{b^{-}}$ center is formed along with a neutral silicon atom that is combined with three oxygen atoms and has one electron on unoccupied orbital [22]. Consequently, at negative voltages (below $-3 \mathrm{~V}$ ) an increase in the reverse current density can be seen (Fig. 4), along with a decrease of the positive charge value on the boundary (Fig. 5).

In Fig. 6 the dependence of $p$-Si crystals resistance on elastic mechanical load is shown.

At the initial stage of the deformation, the ratio of the resistance value to the initial resistance value of $\mathrm{Al}-\mathrm{Si}-\mathrm{Al}$ structure increases linearly. For the as-grown sample, the decrease in the rate of change of the curve can be seen at the stress over 18.8 MPa and the curve saturation occurs at the pressures over $36 \mathrm{MPa}$.

As shown in [26], the aluminium film on the silicon surface creates a supplementary mechanical field, which can amplify the gettering intensity of defects and impurities. With the growth of the elastic deformation pressure up to $18.8 \mathrm{MPa}$, the subsurface layer of the $\mathrm{Al}-\mathrm{Si}-\mathrm{Al}$ structure enriches itself with such complexes that effectively dissipate primary charge carriers and, 
consequently, cause an increase in resistance. But, at the pressure higher than $18.8 \mathrm{MPa}$, the efficiency of this process decreases. This can be due to the layering of another silicon mechanically stimulated process.

In $[27,28]$ it is shown that during the compression of the crystal lattice in $p$-type silicon, the correlation between light and heavy holes can be changed. This leads to a reduction of in the effective mass of heavy holes and reduced resistance.

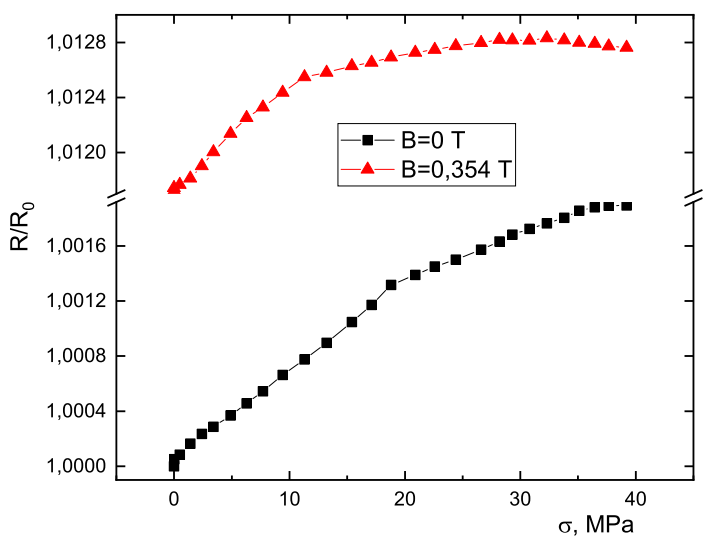

Fig. 6. Dependence of the electrical resistance of the $p$-Si crystal on the magnitude of elastic mechanical deformation $(<40 \mathrm{MPa}) . \mathrm{R}_{0}$ is the value of the initial resistance of the $p$-Si sample

As a result of these two opposed processes, a change in steepness can be observed, as well as saturation emergence at high pressures.

In the sample that has gone through 300 hours of magnetic treatment, changes are similar but made with less deformation force (11.3 and $28 \mathrm{MPa}$ accordingly). This shows that the free holes concentration in the sample exposed to the magnetic field is smaller than in the as-grown sample, because of the acceptor passivation with oxygen. That is why gettering processes and the generation of new holes occur faster and with lower pressures.

\section{CONCLUSION}

Structures based on $p$-Si change their surface resistance in the magnetostatic field with the induction of $B=0.354 \mathrm{~T}$ based on the exposure time.

300 hours of magnetic exposure causes the decomposition of absorbed hydrogen-containing complexes on the surface of silicon. Also, exposure to a MF leads to the passivation of acceptor bonds, which reduces the conductivity of the $\mathrm{Al}-\mathrm{Si}-\mathrm{Al}$ structure and degrades the rectifying properties of the $\mathrm{Bi}-\mathrm{Si}$ contact.

Mechanically stimulated changes of the surface resistance of the $\mathrm{Al}-\mathrm{Si}-\mathrm{Al}$ structure depend on the initial defective state of subsurface layers and the compression ratio.

Magnetic exposure helps to reduce the amount of mechanical stress, at which changes in mechanostimulated effect occur.
[1] R. B. Morgunov, Phys.-Uspekhi 47, 125 (2004); https: //doi.org/10.1070/PU2004v047n02ABEH001683.

[2] Yu. I. Golovin, Phys. Solid State 46, 789 (2004); https: //doi.org/10.1134/1.1744954.

[3] A. A. Skvortsov, A. M. Orlov, L. I. Gonchar, J. Exp. Theor. Phys. 93, 117 (2001); https://doi.org/10.113 4/1.1391527.

[4] M. V. Badylevich, Yu. L. Iunin, V. V. Kveder, V. I. Orlov, Yu. A. Osipyan, J. Exp. Theor. Phys. 97, 601 (2003); https://doi.org/10.1134/1.1618345.

[5] A. M. Orlov, A. A. Skvortsov, A. A. Solov'ev, Phys. Solid State 45, 643 (2003); https://doi.org/10.1134/1.15 68999.

[6] A. M. Orlov, A. A. Skvortsov, L. I. Gonchar, Phys. Solid State 43, 1252 (2001); https://doi.org/10.1134/1.13 86459.

[7] V. A. Makara, L. P. Steblenko, N. Ya. Gorid'ko, V. M. Kravchenko, A. N. Kolomiets, Phys. Solid State 43, 480 (2001); https://doi.org/10.1134/1.1356123.

[8] V. A. Makara et al., Phys. Chem. Solid State 7, 131 (2006).

[9] V. A. Makara et al., Phys. Chem. Solid State 10, 193 (2009).

[10] B. V. Pavlyk et al., Metallofiz. Noveishie Tekhnol. 31,
1169 (2009).

[11] V. A. Makara, et al., Semiconductors 42, 1044 (2008): https://doi.org/10.1134/S106378260809008X.

[12] A. A. Skvortsov, A. M. Orlov, A. A. Solov'ev, D. I. Belov, Phys. Solid State 51, 2446 (2009); https ://doi.org/10 .1134/S1063783409120038.

[13] V. A. Makara, O. A. Korotchenkov, L. P. Steblenko, A. A. Podolian, D. V. Kalinichenko, Semiconductors 47, 665 (2013); https://doi .org/10.1134/-S10637826 13050163.

[14] L. P. Steblenko et al., J. Nano- Electron. Phys. 7, 01036 (2015).

[15] V. A. Makara et al., Nanosyst. Nanomater. Nanotechnol. 12, 247 (2014)

[16] B. V. Pavlyk, M. O. Kushlyk, D. P. Slobodzyan, R. M. Lys, J. Phys. Stud. 21, 1601 (2017); https: //doi.org/10.30970/jps.21.1601.

[17] R. M. Lys, B. V. Pavlyk, R. I. Didyk, J. A. Shykorjak, Nanoscale Res. Lett. 12, 440 (2017); https://doi.org/ 10.1186/s11671-017-2210-x.

[18] R. M. Lys et al., Appl. Nanosci. 9, 1775 (2019); https: //doi.org/10.1007/s13204-019-00964-z.

[19] L. Monastyrskyj, O. Aksimentyeva, I. Olenych, L. Yarytska, Visnyk Lviv Univ. Ser. Phys. 44, 271 
(2009).

[20] M. I. Terebinska, Phys. Chem. Solid State 15, 258 (2014).

[21] L. O. Davydenko, A. G. Grebenyuk, Yu. V. Plyuto, Chem. Phys. Technol. Surf. 44, 250 (2013).

[22] D. P. Slobodzyan, B. V. Pavlyk, M. O. Kushlyk, J. NanoElectron. Phys. 7, 04051 (2015).

[23] B. V. Pavlyk et al., Semiconductors 45, 599 (2011); ht tps://doi.org/10.1134/S1063782611050241.

[24] O. V. Koplak, R. B. Morgunov, Chem. Phys. Lett. 643,
39 (2016); https://doi.org/10.1016/j.cplett.2015. 10.078.

[25] O. V. Koplak, M. A. Vasil'ev, R. B. Morgunov, Phys. Solid State 58, 247 (2016); https://doi.org/10.1134/ S1063783416020165.

[26] B. V. Pavlyk et al., Ukr. J. Phys. 58, 742 (2013).

[27] A. A. Skvortsov, O. V. Litvinenko, A. M. Orlov, Semiconductors 37, 15 (2003); https://doi.org/10.1134/ 1.1538532

[28] A. E. Gorin et al., Ukr. J. Phys. 56, 907 (2011).

\title{
МАГНІТОСТИМУЛЬОВАНІ ЗМІНИ ЕЛЕКТРОФІЗИЧНИХ ВЛАСТИВОСТЕЙ ПРИПОВЕРХНЕВОГО ШАРУ КРЕМНІЮ
}

\author{
Б. В. Павлик, Д. П. Слободзян, Р. М. Лис, М. О. Кушлик, Р. І. Дідик, Й. А. Шикоряк \\ Лъвівсъкий начіоналъний університет імені Івана Франка, \\ кафедра сенсорноӥ та напівпровідникової електроніки, \\ вул. Генерала Тарнавсъкого, 10\%, 79017, Лъвів, Украӥна
}

У цій праці наведено результати впливу слабкого магнітного поля (МП) (0,354 Тл) на електрофізичні властивості поверхневих структур на основі $p$-Si.

Показано залежність поверхневого опору $p$-Si від часу експозиції структур $\mathrm{Al}-\mathrm{Si}-\mathrm{Al}$ в постійному магнітному полі з індукцією 0.354 Т. Установлено, що залежність $R=f(t)$ має тенденцію повторення, однак із різним часом експозиції. 3 аналізу ІЧ-спектрів поглинання встановлено, що витримка монокристалічного кремнію в МП тривалістю до 300 год зменшує концентрацію адсорбованих центрів на поверхні, що відповідають валентним коливання простих зв'язків із воднем $\left(\mathrm{C}-\mathrm{H}_{X}\right.$, $\mathrm{Si}-\mathrm{O}-\mathrm{H}, \mathrm{O}-\mathrm{H})$. У результаті вивільнений водень пасивує акцепторні зв'язки та утворює комплекси 3 кремнієм $\left(\mathrm{Si}-\mathrm{H}_{3}\right)$. Як наслідок, зменшується поверхнева провідність та зростає величина відносної зміни опору під час пружної деформації. Показано, що внаслідок магнітної обробки зменшується величина механічного навантаження (40 \%), за якої відбувається зміна механостимульованого ефекту в кремнію р-типу провідності. Зміна гетерування дірок дефектами приповерхневого шару на процес генерації важких дірок відбувається за $\sigma=11.3$ МПа, на відміну від $\sigma=18.8$ МПа для необробленого МП зразка.

Проведено аналіз магнітостимульованих змін вольт-амперних та вольт-фарадних характеристик структур на основі p-Si. Показано, що 300-годинна витримка бар'єрної структури в магнітному полі спричиняє зменшення густини струму через контакт $\mathrm{Bi}-\mathrm{Si}(\mathrm{p})$ в діапазоні напруг від -3 до +5 В. У результаті погіршуються його випрямні властивості. Установлено кореляцію між результатами аналізу ІЧ-спектрів поглинання та розподілом густини поверхневих станів у забороненій зоні кремнію після експозиції зразків у МП. Показано, що перебудова водневомістких та кисневомістких дефектів приводить до утворення $\mathrm{P}_{b}$-центрів на міжфазній границі $\mathrm{Si}-\mathrm{SiO}_{2}$. Це спричиняє зменшення величини додатного заряду в діелектричному прошарку структури $\mathrm{Bi}-\mathrm{Si}(\mathrm{p})$.

Ключові слова: кремній, магнітне поле, пружна механічна деформація, вольт-фарадна характеристика, ІЧ спектри поглинання. 